\title{
Efficacy of botanicals and fungicides against Rhizoctonia solani inciting sheath blight disease on Rice (Oryza sativa L.)
}

\author{
Vipin Kumar ${ }^{1}$, V.P. Chaudhary ${ }^{1}$, Dharmendra Kumar ${ }^{1}$, Ajay Kumar ${ }^{1}$, Sushma Sagar², \\ Sorabh Chaudhary ${ }^{2}$
}

${ }^{1}$ Department of Plant Pathology, Narendra Dev University of Agriculture and Technology, Kumarganj, Faizabad224229 (Uttar Pradesh), INDIA

${ }^{2}$ Department of Agriculture Biotechnology, Sardar Vallabhbhai Patel University of Agriculture and Technology, Meerut- 250110 (Uttar Pradesh), INDIA

*Corresponding author. E-mail: vipinsre489@gmail.com

Received: November 18, 2016; Revised received: April 28, 2017; Accepted: September 7, 2017

Abstract: Among the fungal diseases, sheath blight, caused by multinucleate Rhizoctoniasolani Kuhn (teleomorph: Thanatephorus cucumeris Donk), a ubiquitous pathogen, is an important fungal disease of rice ranking only after blast and often rivalling it. The potential losses due to sheath blight alone in India has been up to $51.3 \%$. In this study an attempt was made to investigate the antifungal efficacy of botanicals viz., neem (Azadirachtaindica), tulsi (Ocimum sanctum), garlic (Allium sativum), onion (Allium cepa), ginger (Zingiberofficinale) and various fungicides namely mancozeb, propiconazole, hexaconazole, carbendazim, and copper oxychlorideagainst Rhizoctoniasolani in vitro by poison food technique. $R$. solaniwas allowed to grow at $5 \%, 10 \%$ concentrations of botanicals and at 200 , $500,1000 \mathrm{ppm}$ of fungicides amended potato dextrose agar (PDA) medium. The effect of botanicals and fungicides on mycelial growth inhibition was recorded after 36, 48 and 72 post hrs inoculation (phi). It was observed that bulb extract of Allium sativumand rhizome extract of Zingiberofficinalesuppressed the mycelial growth (80.19 and 76.32, respectively) @ 10\% followed by leaf extract of Azadirachtaindica(72.78\%) after 72 phi. Among the fungicides, the complete fungal growth inhibition was observed in propiconazole and carbendazim fungicides amended medium.

Keywords: Garlic, Efficacy, Chemical fungicides, Rhizoctoniasolani, Sheath blight

\section{INTRODUCTION}

Rice (Oryza sativa L.) is the most important staple food crop and grown in India providing of $43 \%$ of calorie requirement for more than $70.0 \%$ of the Indian population of the world. Globally, rice annual production of around 497.9 million tonnes with average productivity of 3.9 tonnes/ha (Anonymous, 2016). The annual production of rice in the country is around 103.36 million tonnes (Anonymous, 2016) and the average productivity in the country across all the ecosystems is still around 2 tonnes/hectare of milled rice. In India, Uttar Pradesh ranks $3^{\text {rd }}$ in the production of rice. The annual rice production is around 12 metric tons with the average productivity of about 2 tons/ha (Dwivedi, 2014). Rice cultivation is often subjected to several biotic stresses of which diseases like blast, sheath blight, stem rot and bacterial blight are the important ones (Kumar et al., 2009). Sheath blight in rice is an important soil-borne fungal disease (Rhizoctonia solani Kuhn) causing up to $25 \%$ of yield losses (Zhenget al., 2013). The disease was first reported from Japan in 1910 by Miyake, who named the causal organism Sclerotiumirrular (Miyake, 1910). Subsequently, in Sri Lanka, China and the Philippines the pathogen was identified as Rhizoctonia solani (Park and Bertus, 1932; Wei, 1934; Reinking, 1918). In India, the first report of its occurrence was by Paracer and Chahal (1963) from Gurudashpur, Punjab and later it was reported from Uttar Pradesh (Kohli, 1966).

Presently, no strong genetic sources of resistance are reported against rice sheath blight disease. The rice sheath blight resistance among the cultivable varieties in India currently ranges only from very susceptible to moderately resistant (Kumar et al., 2009). Therefore, integrated management of this disease below its economic threshold is important for increasing the production, productivity and quality of the produce. The use of botanicals in the management of rice sheath blight is gaining importance of late. Different plant extracts are being used all over the world and among them; neem formulations are very effective in controlling the sheath blight incidence as well as in increasing grain yields (Biswas, 2007). Tomato and escarole green manure were reported as the most suppressive ones in suppressing of $R$. solani damping-off on Lepidiumsativum(Pane et al., 2011). Plant extracts that can control the growth of $R$. solani are the extraction of garlic bulb with saponins, extraction of Piceane- 
oveitchiiwith four flavonoids (Song et al., 2011), cauliflower with caulilexins (Soledadeet al., 2006), extraction of Anemarrhenaasphodeloides rhizomes with nyasol (Z)-1, 3-bis (4-hydroxyphenyl)-1.4-pentadiene (Park et al., 2003). Brassica juncea, B.napus, and Sinapis alba which are added to the soil can protect wheat from rot root of $R$. solani(Handiseniet al., 2013). Application of fungicidal mixtures and pesticides for teh control of pest and diseases is common in rice. The compatibility of these chemicals is a pre-requisite for effective management of these biotic diseases. Field studies indicated that combined application of the insecticide imidacloprid (Confidor $200 \mathrm{SL}$ ) at $0.25 \mathrm{ml} / \mathrm{L}$ and the fungicide validamycin (Rhizocin 3L) at $2.5 \mathrm{ml} /$ $\mathrm{L}$ were high compatible and effective in reducing plant hopper and Sheath blight incidence besides contributing to yield increase (Bhanuet al.,2007). Management of this pathogen using varies fungicides such as Carbendazim 50\% WP, Copper oxychloride 50\% WP, Hexaconazole 5\% SC, and Mancozeb 75\% WP has been reported (Ranjanet al., 2005; Kumar et al. 2009; Srirajet al., 2014).

Hence, considering economic importance of the crop and the disease, the present investigation was undertaken to evaluate the efficacy of botanicals and commercial fungicides against $R$. solani and to find out the suitable management practice to mitigate the disease.

\section{MATERIALS AND METHODS}

In vitro effect of botanicals on radial growth of $\boldsymbol{R}$. solani: Efficacy of five plants extract viz., leaves of Neem and Tulsi, Bulb of Garlic and Onion and Rhizome of Ginger which were found most effective against $R$. solani among 16 botanicals (Verma, 2011) were assessed. The detailed description of plants and their parts used in this study are given in Table 1. Fresh leaves, bulb and rhizome were collected and washed thoroughly in double distilled water. Hundred gram of each washed plant material was grinded in Pestle and Mortar by adding equal amount $(100 \mathrm{ml})$ of sterilized water $(1: 1 \mathrm{w} / \mathrm{v})$ and heated at $80^{\circ} \mathrm{C}$ for 10 min in hot water both. The materials was filtered through double layered muslin cloth followed by filtering through sterilized What man No. 1 filter paper and treated as standard plant extract (100\%). The 5.0\% and $10.0 \%$ concentration was made by adding in requisite amount of sterilized potato dextrose agar medium.From the stock solution of these extract $5 \mathrm{ml}$ and 10 $\mathrm{ml}$ solution were added to 95.0 and $90.0 \mathrm{ml}$ of sterilized cooled potato dextrose agar medium. The flasks were thoroughly mixed to obtain a homogenous mixture of the extracts and potato dextrose agar medium under aseptic condition before pouring it into the petridishes. $20 \mathrm{ml}$ medium was poured into each petridishes, 5 treatments having four replications were maintained. Control treatment was maintained by pouring potato dextrose agar medium without plant extracts. The five $\mathrm{mm}$ discs of four days old culture of $R$. solani were cut with sterilized cork borer and placed in the centre of petridish contain botanicals amended PDA medium. The fungus grown on PDA without plant extracts served as control. The plates were incubated at $26 \pm 1{ }^{0} \mathrm{C}$ in BOD. The observations were recorded at 36, 48 and 72 post hrs inoculation. The growth diameter was recorded and percent inhibition was calculated

In vitro efficacy of fungicides on mycelial growth of R. solani: Fungicides evaluation was carried out for their efficacy to inhibit the mycelial growth of R.solaniisolates by "poisoned food technique". The fungicides viz., copper oxichloride, mancozeb, carbendazimhexaconazole and propiconazole were used at concentrations of $200 \mathrm{ppm}, 500 \mathrm{ppm}$ and $1000 \mathrm{ppm}$ Table 2. Stock solution of each fungicide was prepared in distilled water and incorporated into Potato dextrose agar medium and mixed thoroughly before autoclaving. After autoclaving the medium was poured aseptically in sterilized Petri plates of $9 \mathrm{~cm}$ size in inoculation chamber and allowed to cool. Mycelial plugs of the pathogens $(5 \mathrm{~mm})$ taken from a seven days old culture was placed at the centre of each Petri plate and incubated at $27^{\circ} \mathrm{C}$. Three replications were maintained for each treatment. The experiment was arranged in a completely randomized block design. The fungus grown on PDA without any fungicides served as control. The radial growth of colony was recorded at 36 , 48, 72 post hour inoculation and the percent growth inhibition was calculated by using formula (Vincent, 1947).

$$
\mathrm{I}=\frac{\mathrm{C}-\mathrm{T}}{\mathrm{C}} \mathrm{x} 100
$$

Where,

$\mathrm{I}=$ Per cent inhibition of fungal growth

$\mathrm{C}=$ Radial growth of control

$\mathrm{T}=$ Radial growth of treated Petridis.

\section{RESULTS AND DISCUSSION}

In vitro effect of botanicals on radial growth of $\boldsymbol{R}$. solani: Allium sativum(garlic) bulb extract showed maximum inhibition of 59.01\% and 80.19\%@5\% and $10 \%$ concentration respectively at 72 hours post inoculation and it was found significantly superior to other extracts Table 3 . This was followed by rhizome extract of Zingiberofficinale(ginger) and Azadirachtaindica (neem) leaf extract which showed an inhibition of $76.32 \%$ and $72.78 \%$ respectively, @ 10\% concentration at 72 hours post inoculation. All the five aqueous plants extract showed less mycelial growth inhibition at $5 \%$ concentration as compare to $10 \%$ concentration of plants extract.

Plant extract are not only easy to prepare but also nonpolluting to the environment and low priced as compare to commercial fungicides. This is supported by 
Vipin Kumar et al. / J. Appl. \& Nat. Sci. 9 (4): 1916 -1920 (2017)

Table 1. Botanicals and their part used in this study.

\begin{tabular}{llllll}
\hline S. N. & Common name & English name & Botanical name & Family & Part used \\
\hline 1. & Neem & Neem & Azadirachtaindica & Meliaceae & Leaves \\
2. & Tulsi & Tulsi & Ocimum sanctum & Lamiaceae & Leaves \\
3. & Lahsun & Garlic & Allium sativum & Lilliaceae & Bulb \\
4. & Pyaz & Onion & Allium cepa & Lilliaceae & Bulb \\
5. & Adarakh & Ginger & Zingiberofficinale & Zingiberaceae & Rhizome \\
\hline
\end{tabular}

Table 2. Agrochemicals and their concentration used this study.

\begin{tabular}{|c|c|c|c|c|c|}
\hline S. N. & Trade name & Common name & Chemical name & $\begin{array}{l}\text { Concentration } \\
\text { (ppm) }\end{array}$ & $\begin{array}{l}\text { Source of } \\
\text { availability }\end{array}$ \\
\hline 1 & $\begin{array}{l}\text { Bavistin-50 } \\
\text { (WP) }\end{array}$ & Carbendazim & $\begin{array}{l}\text { Methyl 1, 2-3 Benzimidazole-2yl } \\
\text { Carbamate }\end{array}$ & $\begin{array}{l}200,500 \\
1000\end{array}$ & $\begin{array}{l}\text { BASF India } \\
\text { Ltd }\end{array}$ \\
\hline 2 & $\begin{array}{l}\text { Indofil M-45 } \\
\text { (75 WP) }\end{array}$ & Mancozeb & $\begin{array}{l}\text { Manganese ethylene bisditho- } \\
\text { carbamate }\end{array}$ & $\begin{array}{l}200,500 \\
1000\end{array}$ & $\begin{array}{l}\text { India chemi- } \\
\text { cals Company }\end{array}$ \\
\hline 3 & Blitox-50 (WP) & $\begin{array}{l}\text { Copper } \\
\text { oxychloride }\end{array}$ & $\mathrm{Cu} \mathrm{cl} 2,3 \mathrm{Cu}(\mathrm{OH}) 2$ & $\begin{array}{l}200,500 \\
1000\end{array}$ & $\begin{array}{l}\text { RALLIS IN- } \\
\text { DIA Ltd. }\end{array}$ \\
\hline 4 & Tilt-25 (EC) & Propiconazole & $\begin{array}{l}\text { 1-[2-(2, } 4 \text { Dichlorophenyl)-4 Propyl- } \\
\text { 1-3,3-Dioxolan-2-yl)-Methyl]-1H- } \\
\text { 1,2-4 Triazole }\end{array}$ & $\begin{array}{l}200,500 \\
1000\end{array}$ & $\begin{array}{l}\text { Hindustan } \\
\text { CIBA-GEIGY } \\
\text { Ltd. }\end{array}$ \\
\hline 5 & Cantaf- 5 (SC) & Hexaconazole & $\begin{array}{l}\text { 2-(2, 4-Dichloroheyl)-1(1H-1,2,4- } \\
\text { Trizole-1-yl) Rills Agrochemicals } \\
\text { hexan-2-01 }\end{array}$ & $\begin{array}{l}200,500 \\
1000\end{array}$ & $\begin{array}{l}\text { RALLIS IN- } \\
\text { DIA Ltd. }\end{array}$ \\
\hline
\end{tabular}

Table 3. Efficacy of botanicals against $R$. solani in vitro at different time intervals.

\begin{tabular}{|c|c|c|c|c|c|c|c|}
\hline \multirow{2}{*}{$\begin{array}{l}\text { Plant } \\
\text { extract }\end{array}$} & \multirow[t]{2}{*}{ Concentrations } & \multicolumn{2}{|c|}{ Inhibition after $36 \mathrm{hrs}$} & \multicolumn{2}{|c|}{ Inhibition after $48 \mathrm{hrs}$} & \multicolumn{2}{|c|}{ Inhibition after $72 \mathrm{hrs}$} \\
\hline & & $\begin{array}{l}\text { Radial } \\
\text { growth } \\
(\mathbf{m m})\end{array}$ & Inhibition \% & $\begin{array}{l}\text { Radial } \\
\text { growth } \\
(\mathrm{mm})\end{array}$ & Inhibition \% & $\begin{array}{l}\text { Radial } \\
\text { growth } \\
(\mathbf{m m})\end{array}$ & Inhibition \% \\
\hline \multirow[t]{2}{*}{ Neem } & $5 \%$ & 30.25 & $45.0(42.13)$ & 35.25 & $50.60(34.45)$ & 37.18 & $54.49(47.56)$ \\
\hline & $10 \%$ & 19.5 & $64.54(53.43)$ & 21.75 & $69.18(56.29)$ & 22.25 & $72.78(58.50)$ \\
\hline \multirow[t]{2}{*}{ Tulsi } & $5 \%$ & 34.25 & $37.72(37.58)$ & 39.43 & $45.03(42.13)$ & 41.87 & $48.76(44.51)$ \\
\hline & $10 \%$ & 23.0 & $58.18(49.72)$ & 24.75 & $65.51(54.03)$ & 25.75 & $68.49(55.86)$ \\
\hline \multirow[t]{2}{*}{ Garlic } & $5 \%$ & 27.0 & $50.9(45.52)$ & 30.62 & $57.30(49.30)$ & 33.5 & $59.01(50.18)$ \\
\hline & $10 \%$ & 15.0 & $72.72(58.50)$ & 15.68 & $78.13(62.24)$ & 16.18 & $80.19(63.58)$ \\
\hline \multirow[t]{2}{*}{ Onion } & $5 \%$ & 32.0 & $41.81(40.26)$ & 36.25 & $49.47(44.83)$ & 40.5 & $51.06(45.57)$ \\
\hline & $10 \%$ & 21.0 & $61.81(51.83)$ & 23.43 & $67.32(55.12)$ & 24.43 & $70.21(56.51)$ \\
\hline \multirow[t]{2}{*}{ Ginger } & $5 \%$ & 29.25 & $46.81(43.17)$ & 32.81 & $54.26(47.47)$ & 35.0 & $57.17(49.08)$ \\
\hline & $10 \%$ & 17.18 & $68.76(55.98)$ & 18.43 & $74.32(59.54)$ & 19.35 & $76.32(60.87)$ \\
\hline \multirow[t]{2}{*}{ Control } & - & 55.0 & - & 71.75 & - & 81.75 & - \\
\hline & $5 \%$ & 2.23 & 0.81 & 0.27 & 0.86 & 1.79 & 1.51 \\
\hline \multirow[t]{2}{*}{$\mathrm{SEM} \pm$} & $10 \%$ & $2.07+$ & 2.18 & 1.20 & 1.24 & 1.21 & 0.92 \\
\hline & $5 \%$ & 6.63 & 2.43 & 0.81 & 2.58 & 5.32 & 4.49 \\
\hline $\mathrm{CD}$ at $5 \%$ & $10 \%$ & 6.15 & 6.49 & 3.56 & 3.70 & 3.56 & 2.74 \\
\hline
\end{tabular}

the work of Alibi and Olorunju (2004). In their studies, plants sprayed with neem seed extract gave yields higher than the plants sprayed with black soap and cow dung extract. Mishra et al. (2005) also found Zingiberofficinale, Ocimum sanctum; Azadirachtaindica and Allium cepa were effective against $R$. solani causing web blight disease in green gram. Yadav, (2007) found out of 8 plant extracts, Garlic extract gave maximum inhibition in mycelial growth followed by Ginger, Neem, Onion, Dhatura, Tulsi against $R$. solani causing web blight of French bean. Gurjaret al. (2012) reported that $A$. indica and $A$. vera showed inhibition of mycelial growth of the pathogen and can be utilized for the management of fungal diseases caused by the Aspergillusniger, Aspergillusflavus, $R$. solani, $R$. bataticola.Srirajet al. (2014) found Madhucalongifoliaseed and oil extract most effective among the nine botanicals tested against the leaf blight of turmeric. In the present study, garlic bulb extract showed maximum inhibition and it was significantly superior to other plant extract. All the tested botanicals (Neem, Tulsi, Garlic, Onion and Ginger) showed mycelial growth inhibition of $R$. solani over the control.

In vitro efficacy of fungicides on mycelial growth of R. solani: Propiconazole and carbendazim were individually effective against the pathogen even at the lowest concentration of $200 \mathrm{ppm}$ by maximum inhibiting the mycelial growth and sclerotia formation. At 1000 ppm these fungicides completely inhibited the mycelial growth of $R$. solani. It was significantly superior over other fungicides and on par with each other. It was followed by mancozeb, hexaconazole and copper ox- 
Vipin Kumar et al. / J. Appl. \& Nat. Sci. 9 (4): 1916 -1920 (2017)

Table 4. Efficacy of Fungicides against $R$. solani in vitro at different time intervals.

\begin{tabular}{|c|c|c|c|c|c|c|c|}
\hline \multirow[t]{2}{*}{ Fungicides } & \multirow{2}{*}{$\begin{array}{l}\text { Concentration } \\
(\mathbf{p p m})\end{array}$} & \multicolumn{2}{|c|}{ Inhibition after $36 \mathrm{hr}$} & \multicolumn{2}{|c|}{ Inhibition after $48 \mathrm{hr}$} & \multicolumn{2}{|c|}{ Inhibition after $72 \mathrm{hr}$} \\
\hline & & $\begin{array}{l}\text { Radial } \\
\text { growth } \\
\text { (mm) }\end{array}$ & Inhibition \% & $\begin{array}{l}\text { Radial } \\
\text { growth } \\
\text { (mm) }\end{array}$ & Inhibition \% & $\begin{array}{l}\text { Radial } \\
\text { growth } \\
\text { (mm) }\end{array}$ & Inhibition \% \\
\hline & 200 & 4.5 & $92.24(73.78)$ & 6.25 & $91.3172 .84)$ & 6.75 & $91.27(72.84)$ \\
\hline & 500 & 2.5 & $95.68(77.89)$ & 3.0 & $95.65(77.89)$ & 3.75 & $95.99(78.46)$ \\
\hline \multirow[t]{3}{*}{ Mancozeb } & 1000 & 1.0 & $98.27(82.29)$ & 1.25 & $98.25(82.29)$ & 1.37 & $98.24(82.29)$ \\
\hline & 200 & 3.0 & $94.82(76.82)$ & 4.0 & $94.43(76.31)$ & 4.25 & $94.54(76.44)$ \\
\hline & 500 & 1.5 & $97.41(80.72)$ & 1.75 & $97.56(81.09)$ & 1.85 & $97.62(81.09)$ \\
\hline \multirow[t]{3}{*}{ Propiconazole } & 1000 & 0 & $100(90.0)$ & 0.0 & $100(90.0)$ & 0 & $100(90.0)$ \\
\hline & 200 & 4.25 & $92.67(74.21)$ & 5.5 & $92.35(73.89)$ & 6.0 & $92.30(73.89)$ \\
\hline & 500 & 2.0 & $96.55(79.22)$ & 2.5 & $96.51(79.22)$ & 2.75 & $96.47(79 . .22)$ \\
\hline \multirow[t]{3}{*}{ Hexaconazole } & 1000 & 0.25 & $99.56(84.47)$ & 0.35 & $99.29(84.32)$ & 0.5 & $99.35(84.35)$ \\
\hline & 200 & 3.5 & $93.96(75.70)$ & 4.75 & $93.40(75.11)$ & 5.0 & $93.58(71.95)$ \\
\hline & 500 & 1.75 & $96.98(79.86)$ & 2.0 & $97.22(80.37)$ & 2.2 & $97.17(80.19)$ \\
\hline \multirow[t]{3}{*}{ Carbendazim } & 1000 & 0 & $100(90.0)$ & 0.0 & $100(90.0)$ & 0 & $100(90.0)$ \\
\hline & 200 & 5.25 & $90.94(72.44)$ & 6.75 & $90.61(72.15)$ & 7.5 & $90.38(71.95)$ \\
\hline & 500 & 3.0 & $94.82(76.82)$ & 3.75 & $94.78(76.82)$ & 4.0 & $94.86(76.82)$ \\
\hline Copper & 1000 & 1.75 & $96.98(80.02)$ & 2.66 & $96.29(78.91)$ & 2.18 & $97.19(80.37)$ \\
\hline \multicolumn{8}{|l|}{ Oxychloride } \\
\hline \multirow[t]{2}{*}{ Control \% } & & 58.0 & - & 72.0 & - & 78.0 & - \\
\hline & 200 & 1.31 & 1.68 & 1.4 & 0.36 & 1.27 & 1.19 \\
\hline \multirow[t]{3}{*}{$\mathrm{SEM} \pm$} & 500 & 1.28 & 2.21 & 0.33 & 2.48 & 1.21 & 1.61 \\
\hline & 1000 & 0.97 & 0.89 & 0.24 & 1.24 & 0.94 & 0.47 \\
\hline & 200 & 3.89 & 4.99 & 4.16 & 1.08 & 3.78 & 3.56 \\
\hline \multirow[t]{2}{*}{$\mathrm{CD}$ at $5 \%$} & 500 & 3.82 & 6.57 & 0.99 & 7.37 & 3.6 & 4.81 \\
\hline & 1000 & 2.89 & 2.65 & 0.72 & 3.7 & 2.8 & 1041 \\
\hline
\end{tabular}

ychloride at 500 ppm (Table 4). The least effective fungicides were mancozeb and copper oxychloride (98.24\% and $97.19 \%$ respectively at $1000 \mathrm{ppm})$. It was noted that as the concentration of fungicides increased, the mycelial inhibition and sclerotial formation was arrested.

Hunjanet al. (2012) reported that fungicides viz., trifloxystrobin+ tebuconazole, tebuconazole and propiconazole showed higher level of efficacy against $R$. solani of rice in laboratory conditions. Among the new formulations, Nativo and Bavistin were individually effective against the pathogen in inhibiting the mycelia growth and sclerotial production at lower concentration (Srirajet al. 2014). Tiwariet al. (2002) reported that propiconazole and hexaconazole at $1000 \mathrm{ppm}$ concentration completely inhibit the radial growth $R h i$ zoctoniasolani. Gupta (2002) also reported that carbendazim inhibited 95-100 per cent radial growth of Rhizoctoniasolani. In the present study, among different fungicides screened for $R$. solani, propiconazole and carbendazim were individually effective against the pathogen in inhibiting the mycelial growth and sclerotial production even at the lowest concentration of $200 \mathrm{ppm}$.

\section{Conclusion}

In the present study, the different botanicals and fungicides showed as effective control agents against $R$. solani though their efficacy varied among botanicals and fungicides. It was observed that among the five tested botanicals garlic bulb extract @10\% concentra- tion show maximum mycelial growth inhibition of $R$. solani under in vitro condition, and among the five fungicide propiconazeb and carbendazim @, 1000 ppm showed complete fungal mycelia growth inhibition of $R$. solani. Further studies are needed on these promising botanicals to identify potential compounds produced and evaluate other possible mode of actions before going to field studies.

\section{REFERENCES}

Alibi, O. and Olorunju, E.P. (2004). Evaluation of neem seed extract, black Soap and cow dung for the control of Groundnut leaf spot at samara. Nigeria. Arch. Phytopathol. Plant Prot. 37: 123-127.

Anonymous, (2016).Food and Agriculture Originations of the United Nation.

Anonymous, (2016).Press Information Bureau, Government of India, Ministry of Agriculture Feb. 15. 2016. 16: 06 I.S.T.

Bhanu, K.V. Rao, N.M. and Reddy, P.S. (2007). Compatibility of certain promising pesticides against planthoppers and sheath blight in rice. Indian Journal of Plant Protection. 35 (2): 279-282.

Biswas, A. (2007). Evaluation of neem formulations against sheath blight disease of rice. Indian Journal of Plant Protection. 35 (2): 296-298.

Dwivedi, J.L. (2014). Status paper on Rice in Uttar Pradesh. Rice Knowledge Management Portal (RKMP). Directorate of Rice Research, Rajendra nagar. Hyderabad.

Gupta, R.P. (2002). Fungicidal management of web blight of mungbean. J. Mycol. Pl. Pathol. 32 (1): 141.

Gurjar, A. Shahid, A. Masood, A. and Kangabam, S.S. (2012). Efficacy of plant extracts in plant disease management. Agric. Sci. 3: 425-433. 
Handiseni, M. Brown, J. Zemetra, R. and Mazzola, M. (2013).Effect of Brassicaceae seed meals with different glucosinolate profiles on Rhizoctonia root rot in wheat. Crop Protection. 48: 1-5.

Hunjan, M.S. Love, J.S. Pannu, P.P.S. and Thind, T.S. (2011).Performance of some new fungicides against sheath blight and brown spot of rice. Plant Dis. Res. 26: 61-67.

Kohli, C.K. (1966). Pathogenicity and host range studies on paddy sheath blight pathogen RhizoctoniasolaniKühn. Journal and Research. P.A.U. 3: 7-40.

Kumar, R.B.P. Reddy, K.R.N. and Rao, K.S. (2009). Sheath blight disease of Oryzasativa and its management by biocontrol and chemical control in vitro.Electronic Journal of Environmental, Agricultural and Food Chemistry. 8 (8): 639-646.

Mishra, B.D. Sahoo, K.C. Sugata, G. and. Rout, M.K. (2005).In vitro evaluation of plant extracts, oil cakes and agrochemicals against web blight of green gram caused by Rhizoctoniasolani. J. Mycopatho. Res. 43: 255-257.

Miyake, I. (1910). Studies uber die pilze der Reisoplanze in Japan, J. coll. Agric. Tokyo. 2: 237-276.

Pane, C. Spaccini, R. Piccolo, A. Scala, F. Bonanomi, G. (2011). Compost amendments enhance peat suppressiveness to Pythiumultimum, Rhizoctoniasolani and Sclerotinia minor Biological Control. 56: 115-124.

Paracer, C.S. and Chahal, D.S. (1963). Sheath blight of rice caused by rhizoctoniasolaniKühn - A new record in India, Curr. Sci. 32: 328-329.

Park, H.J. Lee, J.Y. Moon, S.S.B. Hwang, K. (2003). Isolation and anti-omycete activity of nyasol from Anemarrhenaasphodeloides rhizomes.Phytochemistry. 64:9971001.

Ranjan, N. Laha, S.K. Bhattacharya, P.M. and Dutta, S. (2005). Evaluation of new fungicidal formulation for controlling the rice sheath blight disease. Journalof Mycopathological Research. 43(1): 113-115.
Reinking, O.A. (1918). Philippine economic plant diseases. Philippine Journal of Science. 13: 165-274.

Soledade, M. Pedras, C. Sarwae, M. G. Suchy, M. Adio, A.M. (2006). The phytoalexins from cauliflower, caulilexins A, B and C: Isolation, structure determination, syntheses and antifungal activity. Phytochemistry. 67: 1503-1509.

Song, Z.W. Chen, X. Du, H. Zhang, L. Lin, H. Xu. (2011). Chemical constituents of Piceaneoveitchii. Phytochemistry. 72: 490-494.

Sriraj, P.P. Sundravadana, S. Adhipathi and Alice, D. (2014).Efficacy of fungicides, botanicals and bioagents against Rhizoctoniasolani inciting leaf blight on turmeric (Curcumalonga L.).African Journal of Microbiology Research. 8 (36): 3284-3294.

Tiwari, R. K.S. Chandravanshi, S.S. Ojha, B.M. and Thakur, B.S. (2002).In vitro and In vivo Efficacy of rice.J. Mycol. Pl. Pathol. 32 (3): 418.

Verma, A.K. (2011). Efficacy of certain botanicals and bioagents against Rhizoctoniasolani (kuhn) causing web blight of mungbean (Vignaradiata) M.Sc. (Ag.) thesis. N.D.U.A.\&T. Kumarganj, Faizabad.

Vincent, J. M. (1947). Distortion of fungal hyphae in presence of certain inhibitions. Nature. 159- 850.

Wei, C.T. (1934). Rhizoctonia sheath blight of rice. Bulletin, College of Agriculture and Forestry. University of Nanking 15: 21.

Yadav, B.C. Gupta, R. P. and Singh, R.V. (2007). Comparative performance of Trichoderma spp. as seed dresser and soil application against Fusarium wilt of Pigeonpea. J. Mycol. Pl. Pathol. 35 (3): 541.

Zheng, A. Lin, R. Zhang, D. Qin, P. Xu, L. Ai, P. Ding, L. Wang, Y. Chen, Y. Liu, Y. Sun, Z. Feng, H. Liang, X. Fu, R. Tang, C. Li, Q. Zhang, J. Xie, Z. Deng, Q. Li, S. Wang, S. Zhu, J. Wang, L. Liu, H. and Li, P. (2013). The evolution and pathogenic mechanisms of the rice sheath blight pathogen. Nature Communic.4: 14-24. 